University of Nebraska - Lincoln

DigitalCommons@University of Nebraska - Lincoln

Faculty Publications from the Harold W. Manter Laboratory of Parasitology

4-1972

\title{
Fessisentis, a Genus of Acanthocephalans Parasitic in North American Poikilotherms
}

Brent B. Nickol

University of Nebraska - Lincoln, bnickol1@unl.edu

Follow this and additional works at: https://digitalcommons.unl.edu/parasitologyfacpubs

Part of the Parasitology Commons

Nickol, Brent B., "Fessisentis, a Genus of Acanthocephalans Parasitic in North American Poikilotherms" (1972). Faculty Publications from the Harold W. Manter Laboratory of Parasitology. 359.

https://digitalcommons.unl.edu/parasitologyfacpubs/359

This Article is brought to you for free and open access by the Parasitology, Harold W. Manter Laboratory of at DigitalCommons@University of Nebraska - Lincoln. It has been accepted for inclusion in Faculty Publications from the Harold W. Manter Laboratory of Parasitology by an authorized administrator of DigitalCommons@University of Nebraska - Lincoln. 


\title{
FESSISENTIS, A GENUS OF ACANTHOCEPHALANS PARASITIC IN NORTH AMERICAN POIKILOTHERMS
}

\author{
Brent B. Nickol \\ Department of Zoology, The University of Nebraska, Lincoln, Nebraska 68508
}

\begin{abstract}
Thirteen of 16 Siren intermedia collected in Union County, Illinois, were infected with from two to 49 specimens of Fessisentis fessus Van Cleave, 1931. There are no previous reports of identified specimens of Acanthocephala from Siren. This is also the first report of $F$. fessus since the original description and represents new host and locality records. Old siren harbor more and larger specimens than do young siren. Intensity of infection and host age do not, however, relate to variability of other morphological features. Two paratypes, the original description, and specimens from siren form the basis for redescription of Fessisentis fessus. It is now realized that the trunk of females may be up to $52 \mathrm{~mm}$ long and unlike all other species of the genus it possesses a subterminal genital pore. It is also known that lemnisci of males seldom reach the anterior testis and that proboscis hooks may be in as many as 21 longitudinal rows. Contrary to the original description, $F$. fessus possesses two retinacula. The proboscis receptacle departs from usual acanthocephalan morphology in consisting of 2 muscular layers of tubular bundles with contractile fibers at the periphery enclosing a central area of noncontractile cytoplasm. Fessisentis necturorum Nickol, 1967, and F. vancleavei Haley and Bullock, 1953, also possess 2 retinacula and have proboscis receptacles identical in construction to those of $F$. fessus. Fessisentis and Fessisentidae are redescribed to conform to this additional information. Acanthocephalus vancleavei Hughes and Moore, 1943, agrees with Fessisentis as redescribed with the exception of cement gland number. One male specimen was reported to have a cement gland number atypical of both Acanthocephalus and Fessisentis. It is felt that this deviation should not be emphasized to the point of obscuring unique features shared with species of Fessisentis. Because of transfer of this species to Fessisentis, a new name, F. friedi, is proposed for F. vancleavei Haley and Bullock, 1953. Richard Heard has collected Fessisentis necturorum near Athens, Georgia, from larval Ambystoma opacum. This represents additional knowledge of host and geographical distribution.
\end{abstract}

In 1931, Van Cleave described Fessisentis fessus as a new species of Acanthocephala and named a new genus, Fessisentis, and a new family, Fessisentidae, to reflect its taxonomic position. He felt that the form of the proboscis receptacle (with a pouchlike thickening containing several prominent nuclei at the posterior end of the outer wall), form of the testes (filiform with indistinct boundaries and extending at least three-fourths the length of the trunk), possession of one retinaculum (rather than two), an unusual number of cement glands (four), and protonephridial organs associated with the uterine bell served as evidence of the distinctness of the Fessisentidae. Van Cleave later recognized that structures originally interpreted as protonephridia are pockets of the selector apparatus (Haley and Bullock, 1953). F. fessus was described from freshwater drum, Aplodinotus grunniens, collected at Money, Mississippi, and until the current paper there is no published record of additional collections.

Hughes and Moore (1943) described Acanthocephalus vancleavei from neotenic, stream-

Received for publication 3 August 1971. dwelling Eurycea tynerensis collected near Tahlequah, Oklahoma. For reasons discussed below, this species is now considered a member of the genus Fessisentis. The only other report of $A$. vancleavei was by Malewitz (1956), who tentatively identified specimens from E. multiplacata collected near Tahlequah, Oklahoma, as A. vancleavei.

In 1953, Haley and Bullock described a new acanthocephalan, Fessisentis vancleavei, from sunfish, Lepomis gibbosus, collected at Durham, New Hampshire. Bullock has since collected $F$. vancleavei from other species of fish (see Materials section), and Fried and Koplin (1967) collected it from white sucker, Catostomus commersoni, taken in Northampton County, Pennsylvania.

Nickol (1967) described Fessisentis necturorum from Necturus beyeri collected near Folsum, Louisiana. F. necturorum has since been collected from larval Ambystoma opacum (see Materials section).

Golvan (1969) expanded the Fessisentidae to include all members of the superfamily Echinorhynchoidea with four cement glands, elongations of the "middle" egg membrane, 
and without trunk spines. This added four genera from freshwater fishes (Echinorhynchoides Achmerov and Dombrowskaja-Achmerova, 1941; Megapriapus Golvan, Gracia-Rodrigo, and Diaz-Ungria, 1964; Paracavisoma Kritscher, 1957; and Rhadinorhynchoides Fukui and Morista, 1937), three from marine fishes (Cavisoma, Van Cleave, 1931; Neorhadinorhynchoides Yamaguti, 1939; and Pseudocavisoma Golvan and Houin, 1964), and one genus (Filisoma Van Cleave, 1928) with species in freshwater and marine fishes to the Fessisentidae.

The only published record of an acanthocephalan from siren to date was by Altig (1967), who recorded an unidentified species from Siren intermedia collected near LaRue Swamp, Union County, Illinois. In April 1970, 16 S. intermedia collected near the site reported by Altig were examined. Thirteen of these were infected with from two to 49 specimens of Fessisentis fessus. No other acanthocephalans were collected. Other amphibians examined from the same area (five specimens of Eurycea longicauda, six of E. lucifuga, and three of Plethodon cinereus) were not parasitized by acanthocephalans. Although Altig's specimens were not available for study, it seems likely that they also were $F$. fessus.

\section{MATERIALS}

This study is based on the following specimens. Acanthocephalus vancleavei: 1 paratype bearing USNM accession number 36872. Fessisentis fessus: 2 paratypes ( 1 female and 1 male) from Aplodinotus grunniens collected at Money, Mississippi, and bearing Van Cleave's accession numbers 2256.26 and 2264.6; 138 (81 females, 57 males) specimens collected in Union County, Illinois, from Siren intermedia; 11 ( 7 females, 4 males) specimens collected by Mr. Andrew Friedrichs, Southeastern Louisiana University, from S. intermedia taken at Manchac, Louisiana. F. necturorum: 75 ( 44 females, 31 males) specimens used by Nickol (1967) in the species description; 16 (9 females, 7 males) specimens collected from larval Ambystoma opacum taken at Sandy Creek near Athens, Georgia, by Mr. Richard Heard, University of Georgia Marine Institute, Sapelo Island. F. vancleavei: 10 ( 6 females, 4 males) specimens collected from Anguilla bostoniensis, Fundulus heteroclitus, and Lepomis gibbosus taken at Newington, New Hampshire, and Esox americanus (collection locality unavailable), all supplied by Dr. Wilbur L. Bullock, University of New Hampshire.

All measurements are in microns unless other- wise stated. Numerals in parentheses are means unless otherwise noted.

\section{Fessisentis fessus Van Cleave, 1931}

(Figs. 5-12)

Fessisentis fessus, type species of the genus, has not been reported since its original description. Subsequent discovery of additional species of Fessisentis and additional information about $F$. fessus have necessitated redescription. Since the redescription is based, in part, on specimens collected from a host species in a different class from the type host and from a different locality, comparison is first made between specimens from Siren intermedia and the original description.

Specimens of Fessisentis fessus from Siren intermedia agree closely with the original description of the species. Specimens from the new host and locality do, however, differ in several respects. Compared to the original description which reports females from 20 to 30 $\mathrm{mm}$ long, females from siren attain a greater length. Those from siren were up to $52 \mathrm{~mm}$ long and averaged $35 \mathrm{~mm}$ long. Length of males from siren did not differ from the original description. Lemnisci were described as often reaching the anterior testis (Van Cleave, 1931), but in an accompanying figure they did not reach that far posteriorly. Only one specimen from siren possessed lemnisci which reached the anterior testis. Specimens from siren agreed with the original description in length of pseudocoelom occupied by male reproductive system and in having lemnisci more than twice the length of the proboscis receptacle. $F$. fessus from siren also agreed with the original description in regard to number of proboscis hooks in each longitudinal row and in the size of these hooks. The original description reported 12 to 16 longitudinal rows, but specimens from siren possessed 15 to 21 rows. Males averaged 17 rows and females 19. Haley and Bullock (1953) remeasured the proboscides of six $F$. fessus paratypes and reported lengths from 315 to 325 in females and 225 to 250 in males. Proboscis lengths of females from siren agreed with the emended length, but those of males were slightly larger, averaging 268. Specimens from siren agreed with the original description with respect to body shape and egg dimensions. 

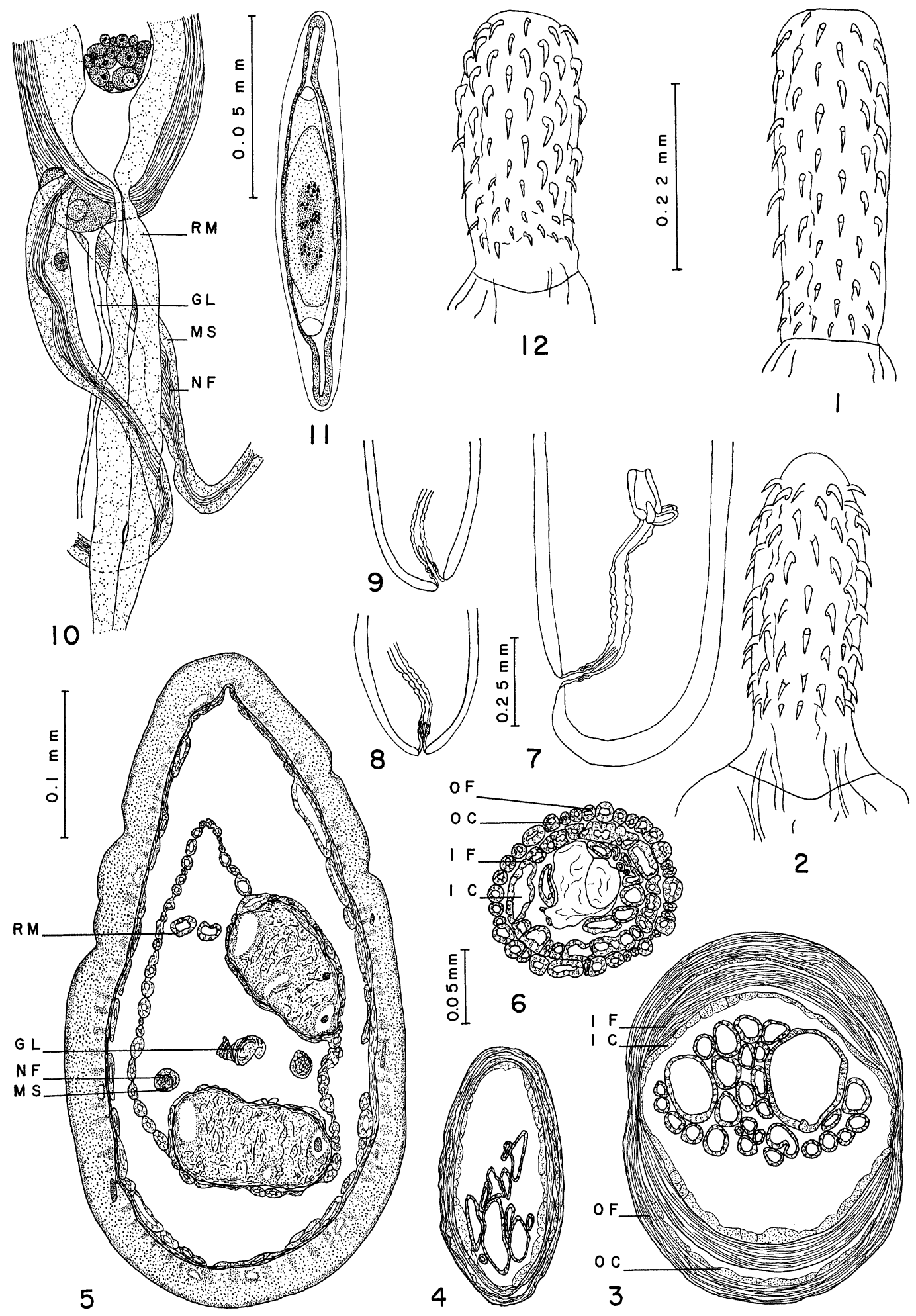
The following redescription of Fessisentis fessus is based on the original description by Van Cleave (1931), emended proboscis measurements of Haley and Bullock (1953), and specimens, including paratypes, mentioned in the Materials section of this paper.

\section{Description}

Body elongate; mature males 10 to $25 \mathrm{~mm}$ (19) long, gravid females 20 to $52 \mathrm{~mm}$ (35) long. Trunk devoid of spines; males average $0.8 \mathrm{~mm}$ and females $1.1 \mathrm{~mm}$ wide at widest point, usually in posterior third of trunk. Females frequently dilated at posterior extremity. Proboscis clavate and with a length of 225 to 307 in males and 302 to 356 in females; maximum diameter 120 to 168 in males, 163 to 240 in females; armed with 12 to 21 longitudinal rows of 6 to 8 hooks each. Sexual dimorphism in proboscis armature undescribed for specimens from fish. In specimens from amphibians, males with 15 to 18 (17) longitudinal rows and females with 16 to 21 (19) rows. Both sexes with 6 to 8 (7) hooks in each row. Hooks in each longitudinal row of two obviously different sizes, usually in combinations of 4 large apical hooks and 3 small, spinelike proximal hooks, or 3 large and 4 small hooks. Large hooks 41 to 60 (46) long and about 14 thick at junction of thorn and root, root prominent; small hooks 12 to 32 (23) long and about 6 thick, root reduced. Neck 112 to 154 (127) long and 149 to 240 (190) wide. Lemnisci nearly always equal in length; usually not lobed; more than twice, and often more than 5 times, length of proboscis receptacle sac; 2.0 to $3.8 \mathrm{~mm}$ (2.9) long in males, only occasionally reaching level of anterior testis; 2.9 to $5.1 \mathrm{~mm}$ (3.8) long in females. Receptacle sac muscular and highly variable in length, 418 to $912(596)$ in both sexes. Receptacle double-walled with outer wall thickened posteriorly to form a pouchlike area containing several prominent nuclei. Musculature of both walls consists of longitudinal, tubular bundles with contractile fibers at periphery enclosing central area of noncontractile cytoplasm. Elongate ganglion near posterior extremity of receptacle sac about 130 long and 60 wide. Two retinacula leave posterior end of receptacle sac and insert on trunk wall. Proboscis invertor muscles penetrate wall of receptacle dorsally at posterior end as a pair of closely associated, fragile retractors. Testes filiform, in tandem, often with indistinct boundaries; 2.5 to $11.2 \mathrm{~mm}$ (4.8) long and 160 to 290 (247) wide. Testes vary greatly in size and are equal, subequal, or single. Regardless of combination, total length of male reproductive system 12 to 15 $\mathrm{mm}$, occupying 65 to $80 \%$ of trunk length. Testes followed by 4 oval to claviform cement glands. Saefftigen's pouch between pairs of cement glands. Cement glands and Saefftigen's pouch greatly variable in size. Female reproductive system, from anterior edge of uterine bell to genital pore, occupies 3.2 to $4.4 \%$ (3.9) of trunk length. Uterine bell 168 to 336 (272) long and 130 to 225 (171) wide. Two large pockets on dorsal wall of bell. Genital pore terminal to subterminal, usually extremely subterminal. Eggs elongate with 4 membranes, fertilization membrane with polar elongations, but lacking knobs. Eggs measured through body wall of fixed females 72 to 103 (93) long and 6 to 14 (12) wide; living eggs in host feces 111 to 124 (114) long and 14 to 19 (16) wide.

Type host: Aplodinotus grunniens.

Additional host: Siren intermedia.

Type locality: Money, Mississippi.

Additional localities: Manchac, Tangipahoa Parish, Louisiana; LaRue Swamp, Union County, Illinois.

\section{Remarks}

Fessisentis fessus is more widely distributed in the southern drainage of the Mississippi River than previously realized. The frequency with which siren are infected, the large size attained, and production of eggs indicate that Siren intermedia is a favorable host for $F$. fessus.

Fessisentis fessus females are characterized by a subterminal genital pore. Although Van Cleave (1931) did not mention genital pore

$\leftarrow$

Abbreviations: GL, genital ligament; IC, noncontractile cytoplasm of inner wall of proboscis receptacle; IF, contractile fibers of inner wall of receptacle; MS, muscular sheath of retinaculum; NF, nerve fiber; $\mathrm{OC}$, noncontractile cytoplasm of outer wall of receptacle; OF, contractile fibers of outer wall of recep-
tacle; RM, retractor muscle.

Figures 1-12. Camera lucida drawings of Fessisentis friedi nom. n., F. necturorum, Echinorhynchus salmonis, Acanthocephalus jacksoni, and F. fessus. (Projection between Figs. 1 and 12 applies equally to Figs. 1, 2, and 12. Projection above Fig. 4 applies equally to Figs. 3, 4, and 6. Projection between Figs. 5 and 10 applies equally to Figs. 5 and 10 .) 1. Proboscis of $F$. friedi. 2. Proboscis of $F$. necturorum. 3. x.s. through proboscis receptacle of E. salmonis. 4. x.s. through proboscis receptacle of A. jacksoni.

Figures 5-12. F. fessus. 5. x.s. through trunk at level immediately posteriad to free end of proboscis receptacle. 6. x.s. through proboscis receptacle. 7-9. Variations in female genital pore position. 10. Terminal portion of proboscis receptacle with associated structures, dissected from trunk. 11. Egg removed from body cavity of fixed female. 12. Proboscis. 
position in the description and figured a female specimen with a terminal pore, the only female paratype examined possesses a distinctly subterminal genital pore. Female specimens collected from siren showed variation in genital pore position (Figs. 7-9), but 80 of 88 possessed subterminal genital pores. The usual genital pore position is illustrated in Figure 7. $F$. fessus is the only species of the genus characterized by females with subterminal genital pores.

Although monorchid specimens of Fessisentis fessus occur, it is the only species of the genus characterized by two testes.

Van Cleave (1931) described Fessisentis fessus as possessing one retinaculum. This became a unique characteristic of the Fessisentidae. Subsequent study has demonstrated that $F$. fessus along with $F$. necturorum and $F$. vancleavei possesses two retinacula (Figs. 5, 10). Proboscis invertor muscles penetrate the dorsal wall of the receptacle sac and continue as a pair of thin, closely associated retractor muscles. Careful study, including examination of transverse sections, is often necessary to ascertain the double nature of these retractors (Figs. $5,10)$. Recognition of nerve fibers in the retinacula permits distinction from retractor muscles.

Species of Fessisentis differ from other acanthocephalans in muscular structure of the proboscis receptacle sac. Descriptions by Kilian (1932), Van Cleave and Bullock (1950), and Nickol and Holloway (1968) have resulted in an understanding of the acanthocephalan proboscis receptacle as a single- or double-walled structure with each wall consisting of either radial or circular contractile fibers with a noncontractile cytoplasmic portion evident as an inner lining. Musculature of the receptacle sac walls described here for $F$. fessus (Fig. 6) is like that of proboscis invertor muscles and represents a departure from usual acanthocephalan anatomy. All other species of Fessisentis examined in cross section ( $F$. necturorum and $F$. vancleavei) possess receptacle sac musculature identical to that of $F$. fessus. Of the North American fauna, Acanthocephalus and Echinorhynchus most closely resemble Fessisentis. Proboscis receptacle musculature has been studied in A. jacksoni and E. salmonis and does not resemble that in species of Fessisentis (Figs. 3, 4, 6).

\section{Fessisentis vancleavi (Hughes and Moore, 1943), comb. $n$. \\ Syn. Acanthocephalus vancleavi Hughes and Moore, 1943}

Hughes and Moore (1943) described Acanthocephalus vancleavei from Eurycea tynerensis collected in Oklahoma. Their description of an extremely elongated "testicular field" with boundaries between testes not clearly observed, together with their illustrations of receptacle sacs (Hughes and Moore, 1943, figs. 1, 5, 15), is strongly suggestive of the genus Fessisentis. Examination of a type specimen (see Materials section) confirms that the posterior end of the proboscis receptacle's outer wall is thickened into a pouchlike area containing several prominent nuclei. Together with the single filiform testis, this distinctive structure of the receptacle strongly indicates that this species should be assigned to Fessisentis. Since it is now recognized that Fessisentis possesses two retinacula, A. vancleavei is substantially in agreement with the diagnosis of Fessisentis.

Hughes and Moore (1943) described and figured seven cement glands in Acanthocephalus vancleavei. Fessisentis is characterized by possession of four cement glands. It should be mentioned that the usual number of cement glands in species of Acanthocephalus is also other than seven. Prominently pouched seminal vesicles of Fessisentis species frequently make determination of cement gland number impossible without study of transverse sections. Since anomalies and duplication of cement glands are known to occur in the Acanthocephala (Van Cleave, 1949; Bullock, 1962), it is felt that possession of other than four cement glands by one specimen of A. vancleavei should not be emphasized to the point of obscuring unique features shared with species of Fessisentis.

Fessisentis vancleavei is smaller than all other species of the genus in nearly every respect except proboscis hook length. The largest hooks of $F$. vancleavei reach a length of 105 and the smallest 45 (Hughes and Moore, 1943). These lengths far exceed those of comparable hooks in all other known species of Fessisentis. Lemnisci of $F$. vancleavei are generally 
branched and subequal. These conditions are known in other species of Fessisentis, but are not usual.

The known geographical distribution of $F$. vancleave $i$ is restricted to the vicinity of Tahlequah, Oklahoma. Thus, it is the only species of the genus known to occur west of the Mississippi River.

\section{Fessisentis friedi, nom. n.} (Fig. 1)

\section{Syn. Fessisentis vancleavei Haley and Bullock, 1953}

Transfer of Acanthocephalus vancleavei Hughes and Moore, 1943, to Fessisentis necessitates renaming $F$. vancleavei Haley and Bullock, 1953. It is proposed that this species be renamed $F$. friedi in honor of Dr. Bernard Fried. Since Fried has contributed to our knowledge of this species, continuity in the literature is retained.

Species of Fessisentis are highly variable and few, if any, single diagnostic characters are recognized. Recognition depends upon comparison of many characters, the ranges of which frequently overlap at the extremes. Lemniscal length seems a relatively consistent difference among species. $F$. friedi possesses lemnisci much shorter than those of $F$. fessus, shorter than those of $F$. vancleavei, and generally longer than those of $F$. necturorum. Fried and Koplin (1967) reported that no branched lemnisci were observed among their specimens of $F$. friedi. This, then, is the only species of Fessisentis in which branched lemnisci have not been observed. Although proboscis shape is variable, $F$. friedi differs from other species of the genus by possession, in general, of a long, cylindrical proboscis (Fig. 1) armed, especially in females, with more hooks per longitudinal row (Fig. 13).

Fessisentis fried $i$ is recorded only from southeastern New Hampshire, southeastern Massachusetts (Haley and Bullock, 1953; Bullock, pers. comm.), and from Northampton County, Pennsylvania (Fried, Kitchen, and Koplin, 1964), suggesting that its distribution may be limited to the northeastern edge of the Appalachian Mountains and the bordering coastal plain. None of several fish and amphibian surveys from the Atlantic's southern coastal plain has reported presence of this species.

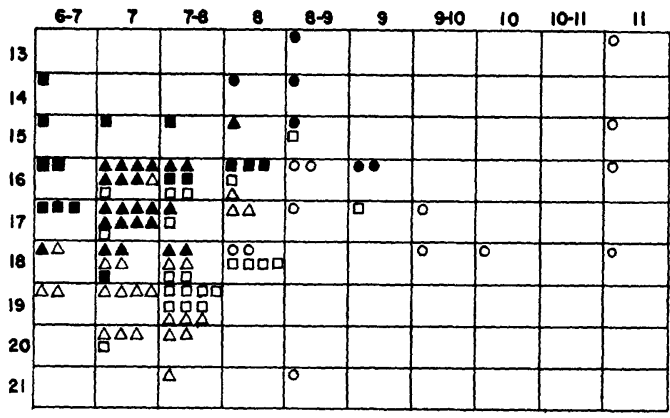

Figure 13. Proboscis armature of three species of Fessisentis showing number of longitudinal rows of hooks (vertical columns) and number of hooks per row (horizontal rows). Data pertaining to $F$. friedi nom. n. are from Fried and Koplin (1967). Each symbol represents a single specimen. Open symbols represent females; solid symbols represent males. Symbols: circles, $F$. friedi; squares, $F$. fessus; triangles, $F$. necturorum.

\section{Fessisentis necturorum Nickol, 1967}

(Fig. 2)

Although the original description of Fessisentis necturorum reported lemnisci from one to two times as long as the proboscis receptacle (Nickol, 1967), their actual length was not given. Lemnisci of $F$. necturorum are 420 to 670 long in males and 770 to 880 long in females. Lemnisci of $F$. necturorum are usually shorter than those of any other species of the genus. In regard to proboscis armature, $F$. necturorum most closely resembles $F$. fessus (Fig. 13), but is distinguished from it by possession of a terminal genital pore in females, much shorter lemnisci, and smaller eggs. Proboscis hooks of $F$. necturorum gradually decrease in length proximally and are not present as two distinct size groups. F. necturorum resembles $F$. friedi in many characters. Although features of proboscis armature overlap at the extremes, series of specimens may be distinguished by these characters (Fig. 13). In general, $F$. necturorum also differs from $F$. friedi in proboscis shape and size (Figs. 1, 2, 12), receptacle sac length, lemniscus length, and testis width.

Knowledge of host and geographical distribution of Fessisentis necturorum was increased when Richard Heard discovered that it parasitized Ambystoma opacum larvae in the vicinity of Athens, Georgia. Previously F. nec- 
turorum had been reported only from Necturus beyeri from southern Louisiana.

Van Cleave's (1931) description of Fessisentis has been emended by Haley and Bullock (1953) and Fried and Koplin (1967). Additional information from this study makes emendation again necessary. Since specimens of all known species of the genus, including types of all except $F$. friedi, have been assembled for comparative study, the following redescription seems warranted.

\section{Fessisentis Van Cleave, 1931}

\section{Diagnosis}

Fessisentidae parasitic as adults in gilled salamanders and freshwater fishes. Trunk elongate and devoid of spines. Proboscis of varying length, clavate to cylindrical, and armed with longitudinal rows of rather weak hooks. Proboscis receptacle sac double-walled with posterior thickening containing several prominent nuclei. Each muscular wall composed of tubular bundles with contractile fibers confined to periphery. Brain in posterior third of receptacle sac. Two retinacula penetrate posterior extremity of receptacle and insert on lateral body walls. A pair of thin retractor muscles leaves posterior tip of receptacle and inserts posteriorly on dorsal wall of trunk. Thick ligament strand inserts at posterior extremity of receptacle and does not always persist in males; always ruptures in females. Male reproductive system occupies 60 to $80 \%$ of body cavity length and includes 1 or 2 filiform testes and 4 cement glands. Uterine bell with large pockets. Female pore terminal to subterminal. Eggs elongate; fertilization membrane elongated at poles, but lacking polar knobs.

Type species: F. fessus Van Cleave, 1931, by original designation.

\section{DISCUSSION}

Fried, Kitchen, and Koplin (1964) reported fluctuation in seasonal distribution of a Fessisentis species later identified by Fried and
Koplin (1967) as F. vancleavei (=F. friedi). They found $F$. friedi in Catostomus commersoni collected in Northampton County, Pennsylvania, present in fall and absent in spring (May). Differences in seasonal distribution may be local and may also vary with Fessisentis and host species. Collection data accompanying specimens provided by Bullock (see Materials section) indicate that $F$. friedi parasitizes Lepomis gibbosus and Fundulus heterclitus at Newington, New Hampshire, during May. $F$. fessus was taken from Siren intermedia during April and F. necturorum parasitizes Necturus beyeri in southern Louisiana from February through November. Waterdogs were not examined during December and January.

A series of 16 siren collected in Union County, Illinois, does not represent an extensive sample, but it suggests that intensity of infection and worm size increase with host size (age). Two siren from this collection with snout-vent lengths exceeding $200 \mathrm{~mm}$ harbored 47 and 49 specimens of Fessisentis fessus. Gravid females from these hosts were 31 to 51 $\mathrm{mm}$ long. Ten infected siren with snout-vent lengths less than $100 \mathrm{~mm}$ harbored a maximum of seven (median, two) specimens. Gravid females from this host group were 23 to 39 $\mathrm{mm}$ long. Mean lengths of these two groups are significantly different with the chance of alpha error less than 5\%. Little information is available concerning longevity of palaeacanthocephalans. In known instances (Van Cleave, 1916; Crompton and Whitfield, 1968) species of Palaeacanthocephala survive less than 1 year in the definitive host. It seems likely, therefore, that differences in specimen size and infection intensity of $F$. fessus in siren are related to

TABLE I. Comparison of morphological features of mature Fessisentis fessus collected from heavy and light infections. Numerals in parentheses indicate size of sample upon which mean measurements or counts are based.

\begin{tabular}{|c|c|c|c|c|}
\hline & \multicolumn{2}{|c|}{ Infections $<10$ worms } & \multicolumn{2}{|c|}{ Infections $>45$ worms } \\
\hline & Male (16) & Female (18) & Male (24) & Female (31) \\
\hline Trunk length ( $\mathrm{mm}$ ) & 17 & 28 & 20 & 41 \\
\hline Proboscis length & 268 & 323 & 268 & 325 \\
\hline \multicolumn{5}{|l|}{ No. long. rows } \\
\hline Prob. hooks & 17 & 19 & 17 & 19 \\
\hline No. hooks/row & 7 & 7 & 7 & 7 \\
\hline Length largest hooks & 40 & 48 & 40 & 50 \\
\hline Lemniscus length ( $\mathrm{mm}$ ) & 2.8 & 3.6 & 2.9 & 3.9 \\
\hline Egg length (through body) & - & 92 & - & 94 \\
\hline
\end{tabular}


available space and increased food (intermediate host) intake respectively in larger siren. The possibility exists, however, that older siren accumulate acanthocephalans during successive years of life. Dr. John D. Lynch, University of Nebraska, placed the age of those specimens under $100 \mathrm{~mm}$ in length at approximately 1 year and that of the two over $200 \mathrm{~mm}$ at 3 or more years. In spite of larger female worms in older hosts with heavy infections, Table I gives evidence that infection intensity and host age do not relate to variability of other morphological features.

Knowledge acquired subsequent to Van Cleave's description of Fessisentis has gradually eroded the distinctive characters of the genus until its place as the only genus of Fessisentidae has been questioned. In deference to possession of four cement glands, Golvan (1969) transferred eight genera of Echinorhynchoidea to Fessisentidae. Van Cleave (1931) discussed the unusual number of cement glands in Fessisentis, but felt that it merely supported family level distinctness of other characters. In view of the fact that the nuclear pouch at the posterior extremity of the outer wall of the proboscis receptacle, muscular construction of the receptacle walls, and form of testes are, as far as known, unique, family level recognition would seem merited. Until other genera with these characters are known, the family Fessisentidae is characterized by Fessisentis, the only included genus.

\section{ACKNOWLEDGMENT}

In addition to those persons acknowledged in the Materials section for providing specimens of Fessisentis, the author is indebted to Drs. John D. Lynch and Michael J. Smith, University of Nebraska, who provided considerable assistance in collection of Siren intermedia. Dr. Ronald A. Brandon, Southern Illinois University, was especially cooperative in arranging laboratory facilities and overnight accommodations near LaRue Swamp.

\section{LITERATURE CITED}

Altig, R. 1967. Food of Siren intermedia netting $i$ in a spring-fed swamp in southern Illinois. Am. Midl. Nat. 77: 239-241.

Bullock, W. L. 1962. A new species of Acanthocephalus from New England fishes, with observations on variability. J. Parasit. 48: 442-451.

Crompton, D. W. T., and P. J. Whitfield. 1968. The course of infection and egg production of Polymorphus minutus (Acanthocephala) in domestic ducks. Parasitology 58: 231-246.

Frued, B., J. G. Krtchen, AND R. S. Koplin. 1964. An intestinal helminth study of Catostomus commersoni from the Bushkill Creek, Northampton County, Pennsylvania, with observations on seasonal distribution of Triganodistomum sp. (Trematoda) and Fessisentis sp. (Acanthocephala). Proc. Pa. Acad. Sci. 38: 95-98.

—, AND R. S. Koplin. 1967. Morphological variation of Fessisentis vancleavei Haley and Bullock, 1953 (Acanthocephala) from the white sucker, Catostomus commersoni (Lacépède). Proc. Pa. Acad. Sci. 40: 53-58.

Golvan, Y. J. 1969. Systématique des Acanthocéphales (Acanthocephala Rudolphi, 1801), l'ordre des Palaeacanthocephala Meyer, 1931, la super-famille des Echinorhynchoidea (Cobbold, 1876) Golvan et Houin, 1963. Mem. Mus. National Hist. Nat. Nouvelle serie A, Zool. 42: 1-373.

Haley, A. J., AND W. L. Bullock. 1953. A new species of Acanthocephala from the sunfish, Lepomis gibbosus (Linnaeus), with a redescription of the family Fessisentidae Van Cleave, 1931. Am. Midl. Nat. 50: 202-205.

Hughes, R. C., AND G. A. Moore. 1943. Acanthocephalus van-cleavei, a new echinorhynchid worm, from a salamander. Am. Midl. Nat. 29: 724-729.

Kilian, R. 1932. Zur Morphologie und Systematik der Gigantorhynchidae (Acanthoceph.). Ztschr. Wiss. Zool. 141 : 246-345.

MalewrTZ, T. D. 1956. Intestinal parasitism of some mid-western salamanders. Am. Midl. Nat. 55: 434-436.

Nickol, B. B. 1967. Fessisentis necturorum sp. n. (Acanthocephala: Fessisentidae), a parasite of the gulf coast waterdog, Necturus beyeri. J. Parasit. 53: 1292-1294.

- AND H. L. Holloway, JR. 1968. Morphology of the presoma of Corynosoma hamanni (Acanthocephala: Polymorphidae). J. Morph. 124: 217-226.

Van Cleave, H. J. 1916. Seasonal distribution of some Acanthocephala from fresh-water hosts. J. Parasit. 2: 106-110.

- 1931. New Acanthocephala from fishes of Mississippi and a taxonomic reconsideration of forms with unusual numbers of cement glands. Tr. Am. Micr. Soc. 50: 348-363.

- 1949. An instance of duplication of the cement glands in an acanthocephalan. Proc. Helm. Soc. Wash. 16: 35-36.

$\longrightarrow$, AND W. L. Bullock. 1950. Morphology of Neoechinorhynchus emydis, a typical representative of the Eoacanthocephala. I. The praesoma. Tr. Am. Micr. Soc. 89: 288-308. 